\title{
Teaching Strategies and Investigative Competences of Postgraduate Students - Faculty of Education - National University of San Marcos, 2017
}

\author{
Junting Xiao \\ Faculty of Education, National University of San Marcos, Lima, Peru
}

Keywords: Teaching strategies, Investigative skills, Cognition, Personal qualities, Metacognition, Professional.

Abstract: This research intends to establish the relationship between teaching strategies and the research competences of postgraduate students - UNMSM, 2017. For this reason, the present scientific study aimed at a quantitative approach of correlational design was established. In order to collect information a questionnaire was elaborated that was applied to the sample conformed by 136 students, to know their points of view with respect to the study variables, also to guarantee its high reliability, the Cronbach's Alpha test was used. On the other hand, the SPSS version 21 computer package was applied, using Spearman's Rho formula with a margin of error of $5 \%$.

Original article, Published date: 2018-04-19

DOI: 10.23977/aetp.2018.21001 ISBN 978-0-9958867-8-0

ISSN: ISSN 2371-9397 (Print), ISSN 2371-9400 (Online)

https://www.clausiuspress.com/journal/AETP.html

\section{Introduction}

The general hypothesis found a very good correlation of Rho $=.848$, since the majority considers how to regulate the teaching strategies, implying with this the assimilation of the investigative competences considered as sometimes adequate. Regarding the first specific hypothesis, a good relation of Rho $=.691$ is confirmed, this due to the majority considerations of regulating specifically the illustrations and questions of the teaching strategies, which could be reflected in the cognitive aspects as sometimes adequate.

The second, the third and the fourth specific hypothesis established a moderate relation of Rho $=.581$, good $\mathrm{Rho}=.612$ and moderate $\mathrm{Rho}=.571$, respectively. Their results allowed to show that the good level of the summaries applied in teaching strategies is insufficient for the dimensions of 
personal qualities, metacognition and professional aspects, considered as sometimes adequate.

Teachers always have to use various resources or tools to ensure the assimilation of new knowledge of students, all this is reduced in the importance of teaching strategies, which will ensure active and participatory learning. However, this importance of the strategies is not evident in the postgraduate courses of the population under study, since most students consider that they meet the academic standards that strengthen the research skills necessary for university education, they include cognition, metacognition, personal and professional qualities.

This context allows us to detail this problem by expanding the theoretical framework of learning strategies and investigative skills. Let's see the following points:

\section{Objective of the investigation}

Know the relationship of teaching strategies with the research skills of graduate students UNMSM, 2017.

\section{Method}

It corresponds to the investigation of the quantitative approach, explanatory level, ex pos facto, since it tries to analyze and evaluate the relationship between the existing variables: teaching strategies and investigative competences. It is non-experimental type with a correlational design.

\section{RESULTS}

For the statistical treatment, the SPSS version 21 computer package was used, with which the hypotheses could be tested. Which are shown below:

PROOF OF GENERAL HYPOTHESIS

HGA. Teaching strategies are significantly related to the research skills of graduate students UNMSM, 2017.

HGO. Teaching strategies are not significantly related to the research skills of graduate students UNMSM, 2017.

TABLE $\mathrm{N}^{\circ} 01$ : Correlation of the general hypothesis

\begin{tabular}{|c|c|c|c|}
\hline & & & $\begin{array}{c}\text { TEACHING } \\
\text { STRATEGIES }\end{array}$ \\
\hline \multirow{6}{*}{$\begin{array}{l}\text { Rho de } \\
\text { Spearman }\end{array}$} & \multirow{3}{*}{$\begin{array}{l}\text { INVESTIGATIVE } \\
\text { COMPETENCES }\end{array}$} & $\begin{array}{l}\text { Correlation } \\
\text { coefficient }\end{array}$ & ,848 \\
\hline & & Sig. (bilateral) &, 000 \\
\hline & & $\mathrm{N}$ & 136 \\
\hline & \multirow{3}{*}{$\begin{array}{l}\text { TEACHING } \\
\text { STRATEGIES }\end{array}$} & $\begin{array}{l}\text { Correlation } \\
\text { coefficient }\end{array}$ & $1,000^{* *}$ \\
\hline & & Sig. (bilateral) & \\
\hline & & $\mathrm{N}$ & 136 \\
\hline
\end{tabular}

Source: Junting Xiao (2017)

Interpretation: When applying Spearman's Rho formula, margin of error at 5\%, a very good correlation coefficient of Rho $=, 848$ and $p=0.000$ was found. Therefore, the null hypothesis is rejected and the alternative hypothesis is accepted, according to the response of the sample, in which the majority considers it as sometimes adequate between the variables research competences and teaching strategies. CONTRASTACIÓN DE LA FIRST SPECIFIC HYPOTHESIS 
TABLE $N^{\circ}$ 02: Correlation of the first specific hypothesis

\begin{tabular}{|c|c|c|c|c|}
\hline & & & $\begin{array}{c}\text { TEACHING } \\
\text { STRATEGIES }\end{array}$ & Cognitive \\
\hline \multirow{6}{*}{$\begin{array}{l}\text { Rho de } \\
\text { Spearman }\end{array}$} & \multirow{3}{*}{$\begin{array}{l}\text { TEACHING } \\
\text { STRATEGIES }\end{array}$} & $\begin{array}{l}\text { Correlation } \\
\text { coefficient }\end{array}$ & 1,000 &, $691^{* *}$ \\
\hline & & Sig. (bilateral) & &, 000 \\
\hline & & $\overline{\mathrm{N}}$ & 136 & 136 \\
\hline & \multirow{3}{*}{ Cognitive } & $\begin{array}{l}\text { Correlation } \\
\text { coefficient }\end{array}$ & ,691** & 1,000 \\
\hline & & Sig. (bilateral) &, 000 & \\
\hline & & $\mathrm{N}$ & 136 & 136 \\
\hline
\end{tabular}

Source: Junting Xiao (2017)

Ha. Teaching strategies are significantly associated with the cognitive dimension of graduate students- UNMSM, 2017.

Ho: Teaching strategies are not significantly associated with the cognitive dimension of graduate students - UNMSM, 2017.

Interpretation: When applying Spearman's Rho formula, margin of error at 5\%, a good correlation coefficient of Rho $=.691$ and $p=0.000$ was found. Therefore, the null hypothesis is rejected and the alternative hypothesis is accepted, according to the response of the sample, in which it mostly refers to it as sometimes adequate between the teaching strategies variable and the cognitive dimension.

\section{Contrastation of the second specific hypothesis}

Ha. Teaching strategies are significantly associated with the personal qualities dimension of graduate students - UNMSM, 2017.

Ho: Teaching strategies are not significantly associated with the personal qualities dimension of graduate students- UNMSM, 2017.

TABLE N $N^{0}$ : Correlation of the second specific hypothesis

\begin{tabular}{lllr}
\hline & & & \multicolumn{1}{c}{ Personal qualities } \\
\hline & TEACHING & Correlation &, 581 \\
STRATEGIES & coefficient &, 000 \\
\cline { 3 - 4 } Rho de Spearman & Sig. (bilateral) & 136 \\
\cline { 2 - 4 } & & $\mathrm{N}$ & $1,000^{* *}$ \\
& Personal qualities & $\begin{array}{l}\text { Correlation } \\
\text { coefficient }\end{array}$ & Sig. (bilateral) \\
\cline { 3 - 4 } & & $\mathrm{N}$ & 136 \\
\hline
\end{tabular}

Source: Junting Xiao (2017)

Interpretation: When applying Spearman's Rho formula, margin of error at 5\%, we find a moderate correlation coefficient of Rho $=.581$ and $\mathrm{p}=0.000$. Therefore, the null hypothesis is rejected and the alternative hypothesis is accepted, according to the sample response, in which most of them affirm as sometimes adequate between the variable teaching strategies and the personal qualities dimension. 


\section{Contrastation of the third specific hypothesis}

TABLE $N^{\circ}$ 04: Correlation of the third specific hypothesis

\begin{tabular}{|c|c|c|c|c|}
\hline & & & & nitive \\
\hline & & TFACHING & $\begin{array}{l}\text { Correlation } \\
\text { coefficient }\end{array}$ & ,612 \\
\hline & & IEACHING & Sig. (bilateral) & 000 \\
\hline Rho & de & & $\mathrm{N}$ & 136 \\
\hline & & & $\begin{array}{l}\text { Correlation } \\
\text { coefficient }\end{array}$ & $1,000^{* *}$ \\
\hline & & Metacognitive & Sig. (bilateral) & \\
\hline & & & $\mathrm{N}$ & 136 \\
\hline
\end{tabular}

Source: Junting Xiao (2017)

Ha: Teaching strategies are significantly related to the metacognitive dimension of graduate students - UNMSM, 2017.

Ho: Teaching strategies are significantly related to the metacognitive dimension of graduate students- UNMSM, 2017.

Interpretation: When applying Spearman's Rho formula, margin of error at 5\%, a good correlation coefficient of $\mathrm{Rho}=, 612$ and $p=0.000$ was found. Therefore, the null hypothesis is rejected and the alternative hypothesis is accepted, according to the sample's response, in which most of them affirm as sometimes adequate between the variable teaching strategies and the metacognitive dimension.

\section{Contrastation of the fourth specific hypothesis}

Ha: Teaching strategies are significantly associated with the professional dimension of graduate students - UNMSM, 2017.

Ho: Teaching strategies are not significantly associated with the professional dimension of graduate students - UNMSM, 2017.

TABLE $N^{\circ}$ 05: Correlation of the fourth specific hypothesis

\begin{tabular}{|c|c|c|c|c|}
\hline & & & $\begin{array}{c}\text { TEACHING } \\
\text { STRATEGIES }\end{array}$ & Professional \\
\hline \multirow{6}{*}{$\begin{array}{l}\text { Rho d } \\
\text { Spearman }\end{array}$} & \multirow{3}{*}{$\begin{array}{l}\text { TEACHING } \\
\text { STRATEGIES }\end{array}$} & $\begin{array}{l}\text { Correlation } \\
\text { coefficient }\end{array}$ & 1,000 &, $571^{* *}$ \\
\hline & & Sig. (bilateral) & &, 000 \\
\hline & & $\mathrm{N}$ & 136 & 136 \\
\hline & \multirow{3}{*}{ Professional } & $\begin{array}{l}\text { Correlation } \\
\text { coefficient }\end{array}$ &, $571^{* *}$ & 1,000 \\
\hline & & Sig. (bilateral) &, 000 & \\
\hline & & $\mathrm{N}$ & 136 & 136 \\
\hline
\end{tabular}

Source: Junting Xiao (2017)

Interpretation: When applying Spearman's Rho formula, margin of error at $5 \%$, we found a moderate correlation coefficient of Rho $=.571$ and $p=0.000$. Therefore, the null hypothesis is rejected and the alternative hypothesis is accepted, according to the response of the sample, in which most of them affirm as sometimes adequate between the variable teaching strategies and professional dimension. 


\section{Conclusions}

- The results confirm discrepancies in the good relationship between the teaching strategies variables and the investigative competences, since the majority considers how to regulate the teaching strategies applied within the study classrooms, implying with this the assimilation of the investigative competences considered as sometimes adequate.

- Regarding the variable teaching strategies and the cognitive dimension discrepancies were determined with respect to their good relationship.

- The teaching strategies and the personal qualities dimension found differences in their moderate correlation, this due to the majority considerations of specifically regulating the illustrations and questions of the teaching strategies, which could be reflected in the personal qualities.

- Between the teaching strategies and the meta-cognitive aspects, they found a good relationship, concluding that the lack of rethinking and improvement of the teaching strategies are damaging the knowledge related to scientific research.

- The moderate relation between the teaching strategies and the professional aspects noticed discrepancies in the results, concluding that the learning strategies are not being given the necessary interest so that the competences acquired with respect to scientific research topics can be used in their activity.

\section{Recommendations}

- The institution under study recommends an exhaustive selection with respect to the teachers who will dictate the postgraduate courses, since these must be trained to select the appropriate teaching strategies that allow to consolidate the investigative competences of the future masters and doctors.

- Teachers should be trained to improve their teaching strategies specifically on the objectives, illustrations and questions.

- The institution under study must schedule trainings to teachers with regard to teaching strategies, in this way they can apply this new knowledge to the classrooms, which will reinforce personal qualities such as relationships with members of graduate courses.

- The institution under study must schedule trainings for teachers with regard to teaching strategies, in this way they can apply this new knowledge to the classroom, which will strengthen the professional aspects noted as personal relationships with members of the graduate courses of the student postgraduate.

\section{References}

[1] Angarita, T. 2000. The educators of the third millennium and the evaluation by competences. Bogotá: Líto FOCET.

[2] Ayala, C., Martínez, R y Yuste, C. (2004). CEAM. Questionnaire of learning and motivation strategies. Manual 1.0. Madrid: EOS

[3] Calderón, M. (2006) State of the research subsystem. Bogotá: Francisco José de Caldas District University.

[4] Cázares, L. y J. Cuevas. (2008) Planning and evaluation based on competencies. Fundamentals and practices for the development of competences. México: Trillas.

[5] Cerda, H. (2007) The formative research in the classroom. Bogotá: Investigate Teaching.

[6] Contijoch, E. (2006). "Relationship between Learning Styles, Learning Strategy and Self Directed Learning. Electronic Journal of the Media Library of CELE-UNAM. READ LANGUAGES IN SELF-DIRECTED LEARNINGCueva, C. Rudy. (2011). Psicología del Aprendizaje. Lima. Editorial San Marcos. Primera Edición.

[7] Díaz Barriga, F. y Hernández, G. (2003). Teaching strategies for meaningful learning: a constructivist interpretation (2 ed.). México: Mc Graw Hill.

[8] Ferreiro, R. (2009) New alternatives to learn and teach. Cooperative learning. México: Trillas. 
[9] Guiselly, Pérez (2015) "Teaching strategies of teachers and learning styles of students in the second and third cycle of the professional academic school of Genetics and Biotechnology of the Faculty of Biological Sciences of the National University of San Marcos Lima - 2012 "Lima - Peru.

[10] Hederich, C. (2004). Doctoral Thesis. "Cognitive Style in the Dimension Independence - Field dependence, cultural influences and implications for Education. Autonomous University of Barcelona.

[11] Hernández, V. (2007) Conceptual maps. México: Alfa omega.

[12] Javaloyes, M. (2016) Teaching of Learning Strategies in the Classroom. Descriptive Study in Teachers of NonUniversity Levels ". University of Valladolid - Spain.

[13] Mayer, R. (2014). Learning and instruction. Editorial Alliance

[14] Pauca, P. (2015) "Learning strategies, motivation for the study and reading comprehension in students of the faculty of education of the UNMSM" Lima, Peru.

[15] Pozo, J. I. (2008). Apprentices and teachers: The cognitive psychology of learning. Madrid: Editorial Alliance.

[16] Prieto, L. (2008) University education focused on learning. Useful strategies for teachers. Barcelona: Octaedro.

[17] Rocha, M. I. P. (2012). Strengthening of investigative competences in the context of higher education in Colombia. Research magazine UNAD, 11(1), 9-34.

[18] Zabalza Miguel A. (2006) The incorporation of autonomous learning and competences into the curricular design of our disciplines. University of Santiago de Compostela. Spain. 